\title{
Effect of Different Salinity Level on Breeding, Fertilization, Hatching and Survival of Nile Tilapia, Oreochromis niloticus (Linnaeus, 1758) in Captivity
}

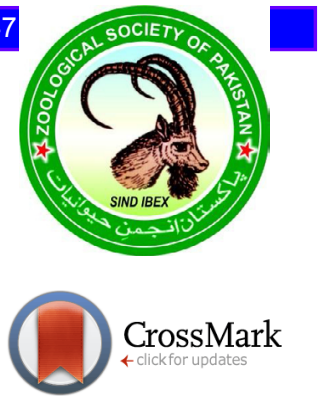

\author{
Abdul Malik ${ }^{1,2}$, Ghulam Abbas ${ }^{1, *}$, Abdul Ghaffar ${ }^{3}$, Sara Ferrando $^{4}$, Lorenzo Gallus ${ }^{4}$ \\ and Syed Sajjad A. Shah ${ }^{2,3}$
}

${ }^{1}$ Centre of Excellence in Marine Biology, University of Karachi, Karachi

${ }^{2}$ Livestock and Fisheries Department, Directorate of Fisheries Sindh, Karachi

${ }^{3}$ Department of Life Sciences, The Islamia University of Bahawalpur,

Bahawalpur,

${ }^{4}$ Department of Earth, Environment and Life Sciences, University of Genoa, Italy

\section{A B S T RA C T \\ This study was conducted to assess optimal salinity level among $0 \%$, $5 \%$, $10 \%$ o $\% \%_{0}, 20 \%$ and $25 \%$ for successful breeding of Nile tilapia, Oreochromis niloticus. The duration of stud tas $56 \mathrm{~d}$. Brooders (48) having mean weight (male $162 \pm 0.2 \mathrm{~g}$ and female $160 \pm 2.5 \mathrm{~g}$ ) selected cto dinto hapa nets in 12 fiberglass tanks (2000-liter). Ratio among male and fo th 1:3. Thoy were fed with commercial floating pelleted feed constituting $35 \%$ crude protein wit $\% \mathrm{~b}$. veight twice a day. Eggs were collected on weekly basis by cultch removal meth Results the the highest fecundity, fertility, hatchability and survival of fry were obtaine sar y of $0 \%$ \% and significantly decreased on $20 \%$ and $25 \%$. The eggs per gram body weight alc ecorded i all treatments and highest eggs were obtained i.e. $4.0-4.3$ per female on $0 \%$ o $\quad\left(28.02 \pm 0.12^{\circ} \mathrm{C}\right)$, dissolved oxygen $(6.4 \pm 0.02 \mathrm{mg} / \mathrm{L}), \mathrm{pH}(7.47 \pm 0.04)$ and amp (less than $22 \pm 0.001 \mathrm{mg} / \mathrm{L}$ ) were monitored throughout the study period. Water quality parame or ined withit recommended range. Our results suggest that Nile tilapia, O. niloticus may e maximu ggs up to $15 \%$ salinity with $92 \%$ survival of fry.}

\begin{abstract}
qua farmin the fastest growing food creating sector, Anow accounts r 50 percent of the total world's food fish (FAO, 2014; Kevin et al., 2015; Malik et al., 2017). Demand for fin fish is expected to exceed all available supplies soon owing to the revolutionary changes taking place in the dietary habits of people all over the world and medical community has promoted fishery products as healthy food (Dawczynski et al., 2010; Siriwardhana et al., 2012; FAO, 2014). Fish and fishery products have recorded the highest increase in price, both in national and international market during recent years, compared to any other food item (Kevin et al., 2015; De Silva, 2016).
\end{abstract}

\footnotetext{
Corresponding author: ghulamabbas@uok.edu.pk 0030-9923/2018/0002-0539 \$ 9.00/0

Copyright 2018 Zoological Society of Pakistan
}

In order to control high prices, aquaculture development has become an urgent need to fulfil shortage of animal protein for human being. In Pakistan, marine or brackish water aquaculture does not exist still now. The climate of Pakistan is arid and semi-arid with scarce and irregular rainfall (Iqbal et al., 2012). Much of its land is affected with salinity and water-logging and the underlain water is brackish (Jarwar, 2006). Such areas can be used for fish culture which will act as a tool for desalinization of the soil through brackish water fish farming (Jarwar, 2014), for which fish seed will be required in plenty. Traditionally, tilapia is cultivated extensively in Sindh. These fishes breed fall under stress in brackish water as salinity affected ecological factors and natural food production (Mateen et al., 2004; Chaughtai et al., 2015; Malik et al., 2017). The breeding of tilapia on optimum salinity level may become useful for its seed production in bulk.

Tilapia culture has been growing fast during the past 
two decades and is becoming the world's second most important finfish group after the carps, presently called as 'aquatic chicken' because of fast growth, easy adaptation into a widespread ecological condition, cultivated within a wide range of densities and reproduce in captivity (SEAFISH, 2011; FAO, 2014; Al-Feky et al., 2015). Tilapia are native to Africa, but have been introduced in 140 countries of the world including Pakistan. Tilapia belonging to genera, Oreochromis are identified as economically valuable fish species for aqua farming and represent a major source of protein in many regions of the world like China, Thailand, Indonesia, Philippian, Vietnam, Africa, Europe, USA, Japan, UAE and Latin America (Chowdhury, 2011; Jaspe et al., 2011; Daudpota et al., 2014, 2016; Malik et al., 2017). Global production of tilapia has reached about 4 million tons in 2013 and is growing at the annual rate of $3 \%-5 \%$. China is the largest producer followed by Egypt, Indonesia, Thailand, Philippines, Brazil, Vietnam and Bangladesh (Fitzsimmons et al., 2011; FAO, 2011). Tilapia are more resistant against diseases. They can breed easily in captivity and there is no need of induced spawning. They are well known for eating variety of foods and can grow best in wide range of ecological situations such as water-temperature, $\mathrm{pH}$, salinity, dissolved oxygen (Daudpota et al., 2014, 2010 Several studies have been done on the culture of tilapia in saline areas (Cnaani and Hulata, 2011; Jaspe et al., 2011; Ahmadi et al., 2015). Due to shortage of fresh waterand increased load to provide food for growing population, tilapia species are now being cultivated in brackish water ponds and in sea cages as well (Cnaani and Hulata, 2011).

The Nile tilapia can only olerate brackish water with salinity up to $25 \%$, while the black tilapia (Oreochromis mossambicus) can tolerate salinity up to $40 \%$ and red tilapia can survive in pure seawater up to $32 \%$ (Jaspe et al., 2011). Due to this, tilapia species are the best option because they are ommivorous and can be easily adapted on artificial feed, survive at low oxygen levels, tolerate a wide range of salinity and can be cultured on low volume with high densities. Tilapia species are productive breeders, they complete their life cycle in confined environment, and have high tolerability against atmospheric stress than carps (Iqbal et al., 2012; Ronald et al., 2014). For sustainable aquaculture of tilapia, availability of good quality seed in mass quantities is the basic requirement. It can be possible through introducing its artificial breeding methods to meet the demands of the fish culturists (Kevin et al., 2015; Iqbal et al., 2016). Therefore, the present study was planned to determine optimal salinity level for breeding of Nile tilapia, Oreochromis niloticus in captivity.

\section{MATERIALS AND METHODS}

\section{Experimental setup}

Experiment was conducted at Seed Production Unit, Hawks Bay, Karachi, Pakistan, for a period of 56 days. Twelve fiberglass tanks (2000-liter water holding capacity) and 12 nylon made hapa were used for this trial. Salinity was maintained by adding some freshwater in the tanks to get desired concentration of salts. Water depth was kept at 3 feet in all experimental tanks.

\section{Brood-stock selection and stocking}

Brood-stock of experimental fish i.e. 36 females and 12 males ranging from $18.6 \pm 0.15 \mathrm{~cm}$ in length and $160.2 \pm 0.2 \mathrm{~g}$ in weight, respectively, were selected on the basis of norphological characters. Subsequently, they were released into the breeding nylon made hapa in breeding tanks for spawning in different treatments like $\mathrm{T}_{1}(0 \%), \mathrm{T}_{2}(5 \%), \mathrm{T}_{3}(10 \%), \mathrm{T}_{4}(15 \%), \mathrm{T}_{5}(20 \%)$ and $\mathrm{T}_{6}$ (25\%), where T represents treatment.

\section{Experimental diet}

Brood-stock were fed artificial floating pelleted feed (35\% crude protein, $5.8 \%$ crude fat, $6.7 \%$ crude fiber, $9.8 \%$ morsture and $8.4 \%$ ash) at $2 \%$ body weight with feeding frequency of 2 times in a day (at 9:00 and 16:00).

\section{Egg collection and incubation}

After 12 days of stocking, all brooders were gathered at the corner of the hapa by means of bamboo and mouth of female's tilapia were checked one by one to get fertilized eggs. These eggs were collected from the mouth of incubating females weekly. After that, these eggs were cleaned and then stocked in incubatory jars separately for further development and hatching process (Ahmed et al., 2007; Valeta et al., 2013). The quantity, length and weight of these eggs were noted. Each incubator was stocked with different egg densities like 2180, 2120, 2100, 2090, 1008 and 560 eggs per incubator. Hatched yolk-sac fry was transferred into rectangular plastic nursing tubs for further development till egg yolk absorption.

\section{Water quality parameters}

Temperature of the tanks water was monitored daily with mercury thermometer. Dissolved oxygen (DO) was noted by using a portable test kit (Merck KGaA, 64271, Germany). The $\mathrm{pH}$ was determined by using $\mathrm{pH}$ meter (EzDO 6011, Taiwan) and ammonia was estimated by portable test kits (Merck KGaA, 64271, Germany) on weekly basis. 
Statistical analysis

Data on fecundity, fertilization of eggs, fry hatchability and its survival were evaluated by analysis of variance (ANOVA) using Minitab 17.0 version statistical software. These factors were calculated by using the following formulae (Brian, 2015; Malik et al., 2017).

$$
\begin{gathered}
\text { Fertilization }(\%)=\frac{\text { No of fertile eggs }}{\text { Total No of collected eggs }} \times 100 \\
\text { Hatchability }(\%)=\frac{\text { No of eggs hatched (fry) }}{\text { No of eggs incubated (fertile) }} \\
\text { Unfertile eggs }(\%)=\frac{\text { No of whitish broken eggs }}{\text { No of eggs fertile }} \times 100 \\
\text { Survival }(\%)=\frac{\text { Final No of fry (after yolk disappears) }}{\text { Initial No of fry (with yolk after hatching) }} \times 100 \\
\text { Egg body weight }{ }^{-1}=\frac{\text { Total No of collected eggs }}{\text { Weight of female }(\mathrm{g})}
\end{gathered}
$$

\section{RESULTS}

Among six treatments, highest fecundity (number of eggs) was found in $\mathrm{T}_{1}, \mathrm{~T}_{2}, \mathrm{~T}_{3}$, and $\mathrm{T}_{4}(2180 \pm 4.2$, $2120 \pm 4.2,2100 \pm 4.5$ and $2090 \pm 3.8$, respectively (Table I) as compared to those of $T_{5}$ and $T_{6}(1008 \pm 21.0$ and $560 \pm 21.0$, respectively). Significant egg fertility was shown in $\mathrm{T}_{1}(2050 \pm 3.2), \mathrm{T}_{2}(980 \pm 3.2), \mathrm{T}_{3}(1955 \pm 5.8)$ and $\mathrm{T}_{4}(1944 \pm 11.0)$. Same results were found for hatchlings in this study. Higher survival of fry was achieved on lower salinity groups (Table I).

Regression analysis showed that the relationship between salinity and breeding component (fecundity, egg fertility, hatchability and survival of fry) was significantly higher up to $15 \%$ salinity level, after which no significant growth was observed (Fig. 1). The quantity of fertile eggs incubated in her mouth was not significantly different up to $15 \%$ salinity. Above this level of salinity, fertile eggs were found to be inversely proportional (Table II). Number of eggs in one gram of fish body weight were recorded in all treatments; higher eggs were found 4.3 to 4.0 in $T_{1}$ to $T_{4}$ Table II)

Table I.- Morphometric and breeding performance of Nile tilapia (Oreochromis niloticus) on different Salinity during 56 days.

\begin{tabular}{|c|c|c|c|c|}
\hline Salinity (\%o) & Total length (cm) & Total weight (g) & Fertilized eggs/Female & Fertilized eggs/(g) \\
\hline 0 & $18.8 \pm 0.75$ & $160.5 \pm 2.16$ & $683 \pm 6.0$ & $4.3 \pm 0.14$ \\
\hline 5 & $18.6 \pm 0.74$ & $160.5 \pm 2.12$ & $660 \pm 4.1$ & $4.1 \pm 0.13$ \\
\hline 10 & $18.5 \pm 0.60$ & $160.0 \pm 2.65$ & $652 \pm 4.0$ & $4.1 \pm 0.13$ \\
\hline 15 & $18.7 \pm 0.43$ & $160.2 \pm 2.20$ & $648 \pm 2.4$ & $4.0 \pm 0.12$ \\
\hline 20 & $18.4 \pm 0.29$ & $160.0 \pm 2.60$ & $254 \pm 6.1$ & $1.6 \pm 0.12$ \\
\hline 25 & $18.6 \pm 0.28$ & $160.0 \pm 2.60$ & $107 \pm 7.0$ & $0.7 \pm 0.1$ \\
\hline
\end{tabular}

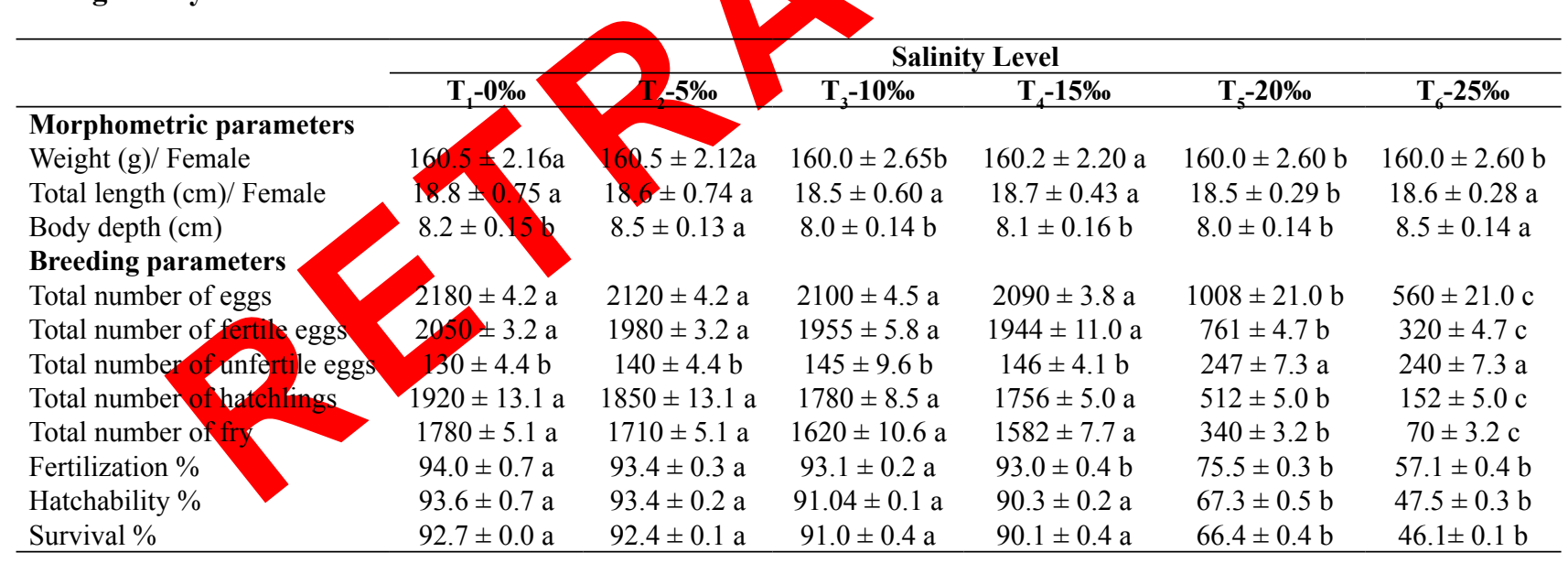

Different letters in the same row represent significant difference $(P<0.05)$ values are mean \pm standard error.

Table II.- Average data record of collected fertilized eggs of Nile tilapia (Oreochromis niloticus) with respect to the female parent tilapia size (cm) weight (g) on different salinity levels.

For statistical data, see Table I. *Number of eggs per gram= total number of eggs/weight of female (g). 

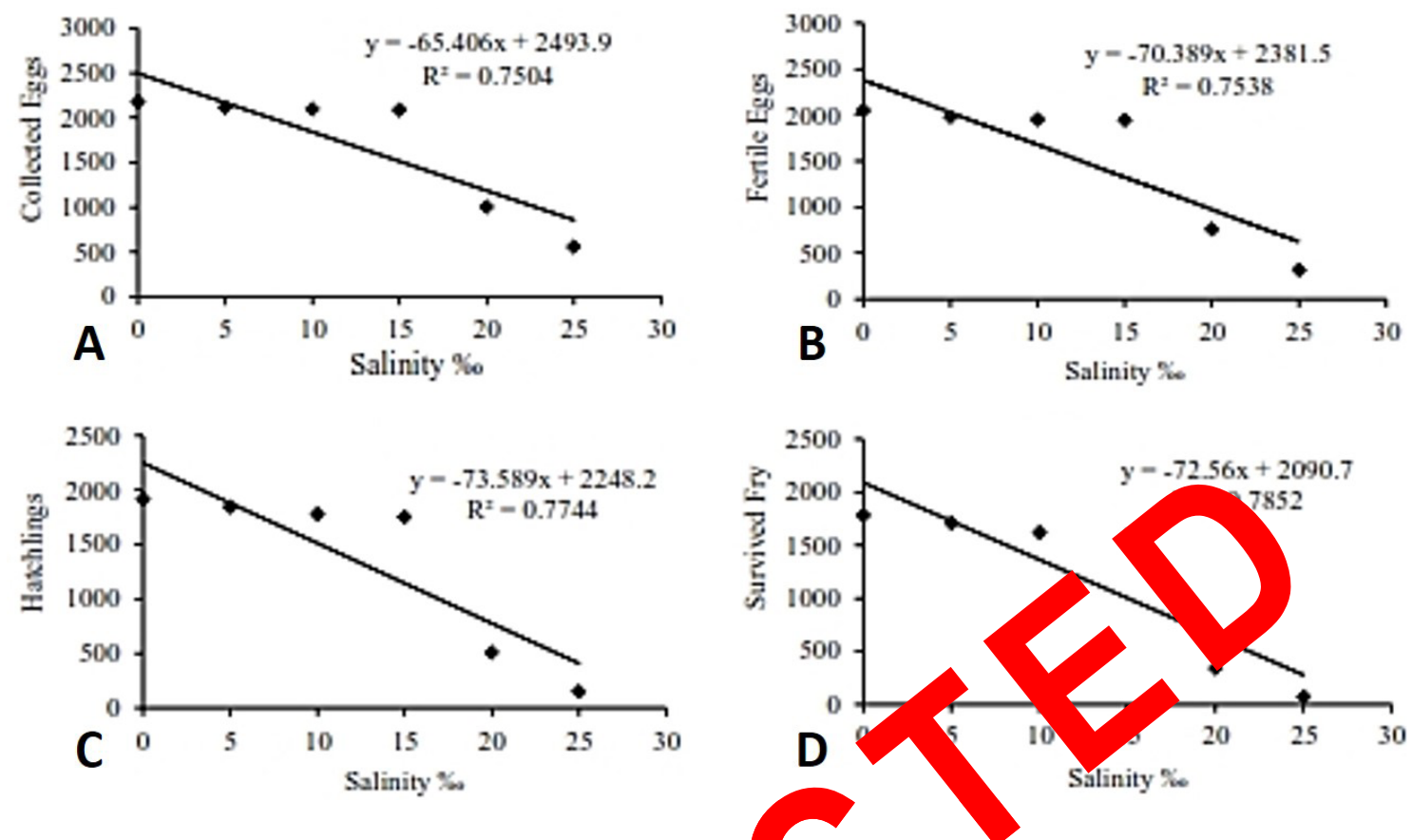

Fig. 1. Regression of salinity on fecundity (A), fertility (B), hatcha lity (C) $\sim \mathrm{d}$ fry (D) of Nile tilapia (Oreochromis niloticus) among all treatments.

Embryonic development of Nile tilapia was divic into 6 phases: zygote to cleavage (Fig. 2A), bra tra ( $\mathrm{F}_{\mathrm{r}}$ 2B), gastrula (Fig. 2C), pharyngula (Fig $D$ ), ttchin (Fig. 2E, F), larval (Fig. 2G, H) and iuve Zygote to cleavage phase began $f, 0-1,24$ arter post fertilization and one day $i \hat{a}$. ost fert ation, it characterized with cytop mic gro h, formation of blastodisc at the end of amal-pole, pre ace of different perivitelline gape and ge phase categorized with a sequence of ic pa ron rat resulted in several blastomeres astu phase an from $4-20 \mathrm{~h}$ after post fertilization an fter post fertilization, categorized with 2 differen oatings of blastoderm, external outer layer and a perip cy multinucleate mass of cytoplasm resulting from fusion of cells. The gastrula phase began from $20-40 \mathrm{~h}$ after post fertilization and 2 days after post fertilization, germ ring surrounding the margin of the blastoderm; it is the main characteristics of this phase and embryonic protection layer stretched from germ ring towards the animal pole and form the neural tube. Phase pharyngula began from $40-88 \mathrm{~h}$ after post fertilization and 2-4 days after post fertilization, considered by primordia of pharyngeal arches, which were present but very difficult to differentiate individually at earlier periods. Hatching phase began from $88-116 \mathrm{~h}$ post fertilization and 4-5 days after post fertilization, categorized by the formation and differentiation of tissues and organs of pharyngeal skeleton. The phase larval development starts after hatching phase till the end of yolk absorption started 1.vm 116-274 h post fertilization and 5-12 days after post fertilization. This phase gradually started with the movement of jaws, operculum flapper, and pectoral fins. Distinguish by inflation of the hydrostatic organ (swim bladder) became functionalized and pharyngeal skeleton prior to starting exogenous feeding. The phase juvenile development began after larva stage and developed all body parts completely and looked like parents until the first maturation of gametes. This stage starts from 306$672 \mathrm{~h}$ after post fertilization and 13-28 days after post fertilization (Table III).

Table III.- Developmental stages of Nile tilapia (Oreochromis niloticus) during the study period.

\begin{tabular}{llcc}
\hline Developmental stages & $\begin{array}{c}\text { Hours } \\
\text { post-fertilization }\end{array}$ & $\begin{array}{c}\text { Days } \\
\text { post-fertilization }\end{array}$ \\
\hline Embryo & Cleavage & $2-4$ & 1 \\
& $(2-32$ cells $)$ & & \\
& Blastula & $4-20$ & 1 \\
& Gastrula & $20-40$ & 2 \\
& Pharyngula & $40-88$ & $2-4$ \\
& Hatching & $88-116$ & $4-5$ \\
Larva & Early larva & $116-140$ & $5-6$ \\
& Late larva & $208-274$ & $9-12$ \\
Juvenile & Early juvenile & $306-352$ & $13-15$ \\
& Late juvenile & $552-672$ & $23-28$ \\
\hline
\end{tabular}




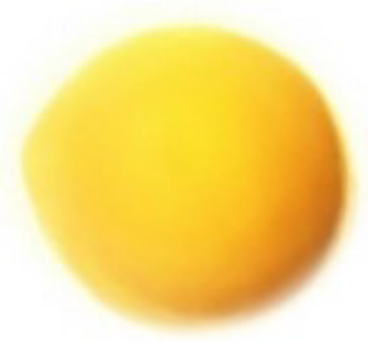

(A) Embryo (Cleavage) day-1

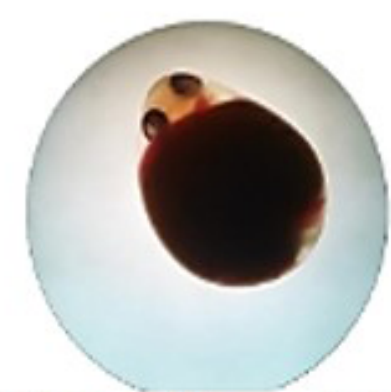

(D) Embryo (Pharyngula) day$3-4$

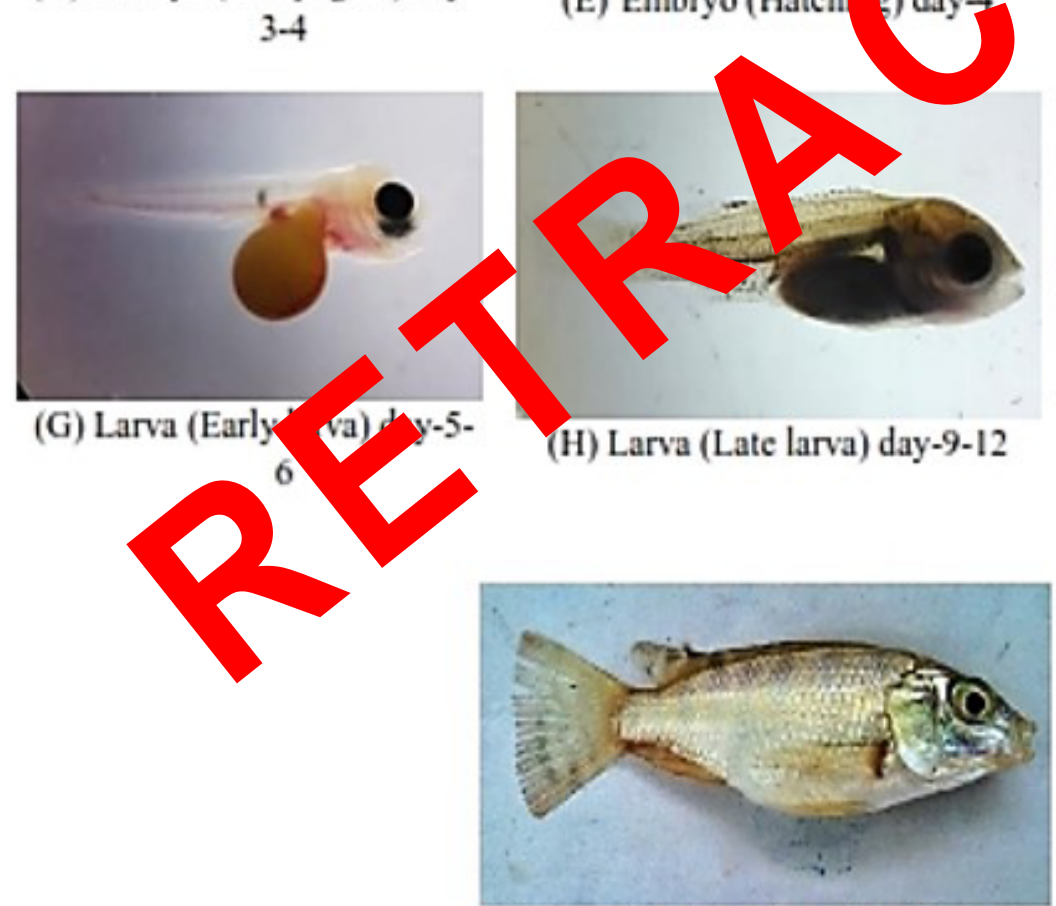

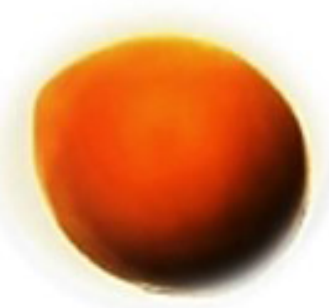

(B) Embryo (Blastula) day-1

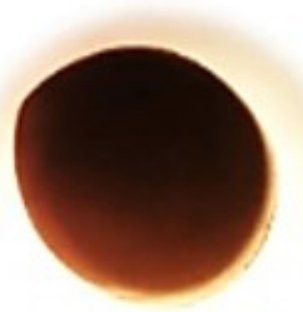

(C) Embryo (Gastrula) day-2

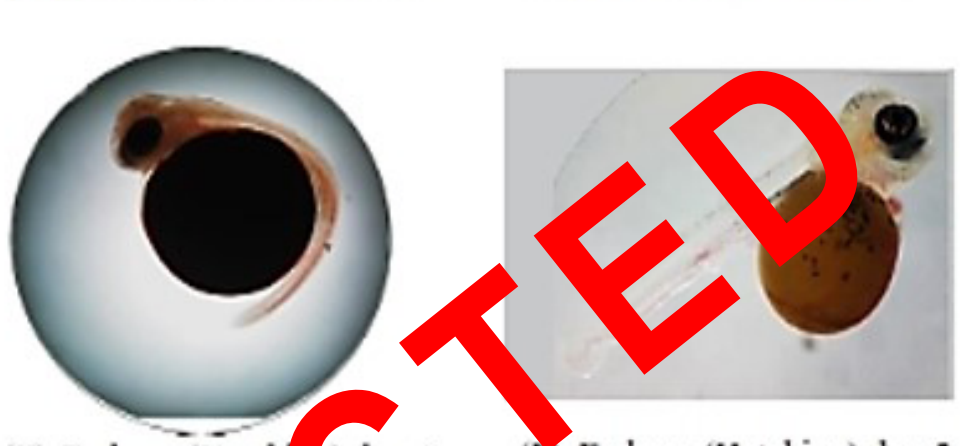

(E) Embryo (Hatch day-4 (F) Embryo (Hatching) day-5

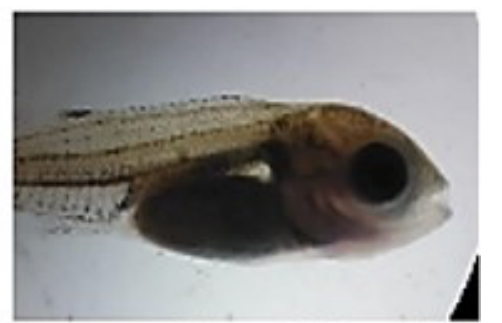

(1) Juvenile (Early juvenile) day-13-15

(J) Juvenile (Late juvenile) day-23-28

Fig. 2. Egg to juvenile development stages of Nile tilapia: fertilized egg yellow in color at the first day (A, B) than yellow brown and yolky; at second day small dark spots are appeared on the egg surface $(\mathrm{C})$; from third day and fourth day eyes and hair-like tail appeared (D \& E); at the fifth day head appeared (F); from fifth day to sixth day head and tail further more developed, yolk sac decreased and the embryo started slight movement $(\mathrm{G})$; on ninth day to twelfth day post-yolk sac appeared at this stage yolk sac was completely absorbed and fry started to feed on artificial diet $(\mathrm{H})$. On thirteenth day to fifteenth day fins and other body parts are developed completely and reached about $0.5 \mathrm{~g}$ in weight (I). Finally reached $1-2 \mathrm{~g}$ in weight and look like parent after twenty third day to twenty-eighth day (J). 


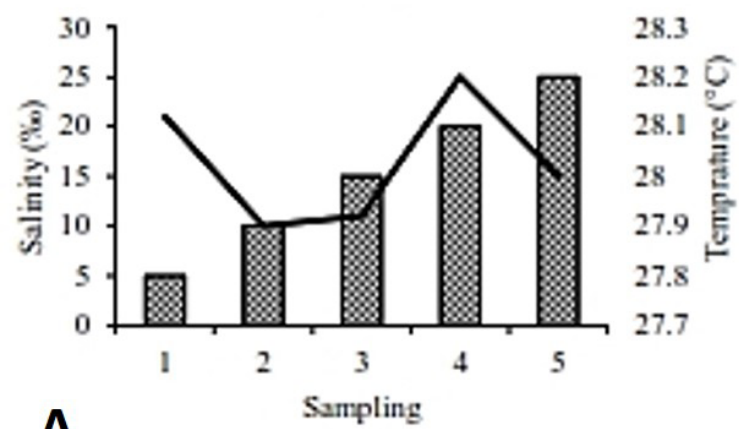

A

masos Salinity $(\%) \quad-$ Temperature $\left({ }^{\circ} \mathrm{C}\right)$

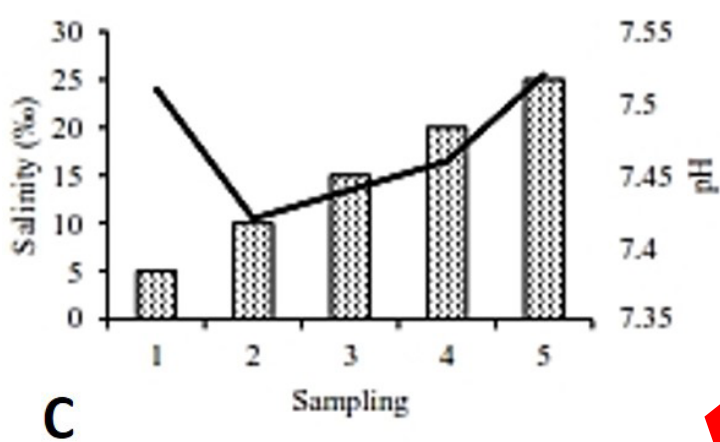

\section{B}
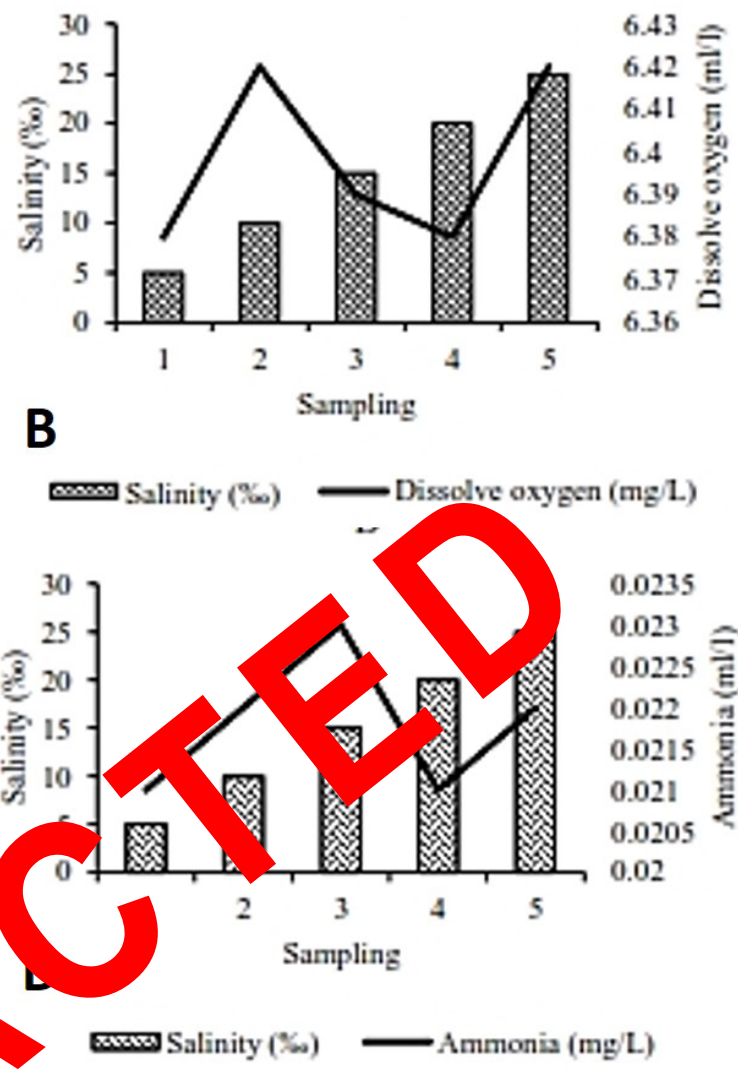

Fig. 3. Water quality parameters recorded du on different salinity levels.

Water quality paramets are giv in Table I. Water temperature did not $y$ more than degree among replicates throughout perimental period; mean values were $\left(27^{\circ} \mathrm{C}\right.$ to $8.2^{\circ}$ mean $\left.28.03 \pm 0.2^{\circ} \mathrm{C}\right)$. Salinity of from $0 \%$ to ra $25 \%$. No statistically $\mathrm{s}_{\mathrm{i}} \mathrm{i}$ difference $(P>0.05)$ was found in dissolved oxygu concentration $(6.38 \mathrm{ml} / 1$ to $6.42 \mathrm{ml} / \mathrm{l}$, mean $6.4 \pm 0.02 \mathrm{~m}$. There was no significant effect of introduced feed on $\mathrm{pH}$ of saline water in each tank. The $\mathrm{pH}$ values were observed as 7.42 to 7.52 with mean of $7.47 \pm 0.04$ and ammonia remained as $0.022 \pm 0.001 \mathrm{ml} / 1$ throughout the experiment (Fig. 3).

\section{DISCUSSION}

It is well known fact that sustainable aquaculture requires healthy seed in mass quantity of commercially important specie which can be possible through artificial egg incubation and nursing at small to large scale hatcheries. This can also be monitored through several aspects such as brood-stock management, breeding methods, nursing techniques, farming and marketing.

This research work provides information about ability to produce maximum eggs and survival of Nile tilapia (O. niloticus) fry on different salinity levels in captivity. Maximum percentage of fertilized eggs were obtained among treatments; 1, 2, 3 and 4 (93\%-94\%). These results are more or less similar with the findings of Brian (2015). He got $82 \%-85 \%$ fertilized eggs from $O$. niloticus stocked in seawater tanks. Rodriguez-Montes de Oca et al. (2015) found $66.7 \%, 71.8 \%$ and $65 \%$ fertilized eggs from Nile tilapia on different salinity levels i.e. $0 \%$, 5\%o and 15\%o. Rehman et al. (2015) reported 67\%-81\% fertilization rate with $\mathrm{HCG}+\mathrm{HMG}$ and $\mathrm{HCG}+\mathrm{Ovaprim}$ artificial stimulating hormones on snakehead fish (Channa marulius). Furthermore, Akinwande et al. (2012) achieved $80 \%$ fertilization rate of Clarias species (intraspecific hybrids). These results are in agreement with the findingds of the present study. Evidence to support this is available in another study of Martins et al. (2015) who investigated the effect of salinity on artificial reproduction of silver catfish (Rhamdia quelen) and reported 85\%-93\% fertilization rate. Similar results have been reported by Abdel-Hakim et al. (2008). 
Significant research on different strains of Nile tilapia showed 89\%-92\% hatching (Almeida et al., 2013) which are in contrast with the results of 1-4 treatments of our study. Akinwande et al. (2012) reported hatchability rate $79.1 \%-83.3 \%$ in Clarias spp. Martins et al. (2015) while studying on some other fish species reported significant results $(83.3 \%)$ at $0 \%$ salinity for silver catfish, Rhamdia quelen. Young-Sulem et al. (2008) obtained maximum hatchability $(65.3 \%)$ at various turbidity levels for Clarias gariepinus.

In the present study, highest survival rate of Nile tilapia, O. niloticus fry was found as $90.1 \%$ to $92.7 \%$ in treatment groups of 1-4. These obsevations are in coincidence with the results of Abdel-Hakim et al. (2008). Mubarik et al. (2015) have documented survival rate (39.4\%-91.0 \%) of common carp fry on different rock salt concentration $(0-30 \mathrm{mg} / \mathrm{L})$. On the other hand, Brian (2015) reported survival rate of fry as $71.4 \%$ in Nile tilapia with subject to red background color of the tank. Moreover, Olufeagba and Okomoda (2015) obtained survival rate of $10.47 \%-90.4 \%$ on parental and experimental crosses in Heterobranchus longifilis. However, our results are in between of these findings. The number of eggs (1.7-4.05) per gram body weight were similar to the study of Ahmed et al. (2007). They obtained 1-5 eggs per gram body weight in Tilapia niloticus and greater than Mashaii et at (2016) They got $2.77 \pm 0.13 \mathrm{eggs} / \mathrm{g}$ on Nile tilapia in brackish water. In the present study, embryonic development took 552-672 $\mathrm{h}$ post fertilization (hpf) period and 23-28 days' post fertilization (dpf) period and it showed short time from the previous findings reported $600-720 \mathrm{hpf}$ and 25 $30 \mathrm{dpf}$ on similar specie by Fujimura and Okada (2007). The variations in our results might have been due to climatically and geographical changes or environmental factors such as temperature, dissolved oxygen etc. Water quality parameters were suitable for Nile tilapia during the breeding period and more or less similar with the findings of previous scientists (Nandlal et al., 2004; Hussain, 2004; Ahmed et al., 2007; Khalfalla et al., 2008; Valeta et al., 2013; Ahmadi et al., 2015; Daudpota et al., 2016). They recommended that water temperature $\left(22^{\circ} \mathrm{C}-30^{\circ} \mathrm{C}\right)$, dissolved oxygen (4.0mg/L-8.0mg/L, pH (6.5-9.0), ammonia $(0.01 \mathrm{mg} / \mathrm{L}-0.1 \mathrm{mg} / \mathrm{L})$ are suitable for the normal growth and successful breeding of tilapia.

\section{CONCLUSION}

The findings of the present study suggest that Nile tilapia, $O$. niloticus can breed successfully up to $15 \%$ salinity and may get maximum fertilization, hatchability and survival rate of fry. Owing to climate change and sea intrusion our agricultural land in Sindh has become saline, due to which agriculture production may be effected as well. These areas may be utilized for fish farming to overcome the protein deficiency especially animal origin and will be the source of income for the peoples of these areas. In this way, our aquaculture sector will be promoted.

\section{ACKNOWLEDGEMENTS}

The senior author is grateful to the HEC for providing fellowship to complete this work as a part of Ph.D. research. He is very thankful to Mr. Ghulam Muhammad Mahar, Director General Fisheries Sindh, Mr. Athar Mian Ishaqi, Director, Research and Development Karachi, for their permission to use the facilities throughout the study. He is much grateful to Mr. Muhammad Hanif Soomro, Deputy Director Fisheries (In-charge) Seed Production Unit Hawaksbay Karachi for supporting in all hatchery facilities to conduct this study smoothly and Mr. Mansoor Zafar, Assistant Director Fisheries Sindh for his cooperation and help during this research.

tatement of conflict of interest

Authors have declared no conflict of interest.

\section{REFERENCES}

Abdel-Hakim, E., Gamal, E., Zeinab, A. and Greisy, E., 2008. Effect of removal of eggs adhesiveness on hatchability and effect of different levels of salinity on survival and larval development in common carp Cyprinus carpio. J. appl. Sci. Res., 4: 19351945.

Ahmadi, N., Baroiller, J.F., Cotta, H. and Morillon. R., 2015. Adaptation to salinity. In: Climate change and agriculture worldwide (ed. E. Torquebiau). Springer, pp. 45-58.

Ahmed, A.M., Abdalla, S. and George. T.T., 2007. Egg enumeration, incubation, hatching and development of the Miracle Fish Oreochromis niloticus, in the Sudan. Aquacult. Canada. AAC. Spec. Publ., 12: 60-64.

Akinwande, A.A., Fagbenro, O.A. and Adebayo, O.T., 2012. Fertilization, hatchability, survival and larval biometry in interspecific and intergeneric hybridization in Heterobranchus longifilis, Clarias gariepinus and Clarias anguillaris under controlled hatchery conditions. Elixir Aquacult., 43: 66966700.

Al-Feky, S.S.A., El-Syed, A.F.M. and Ezzat, A.A., 2015. Dietary taurine enhances growth and feed utilization in larval Nile tilapia (Oreochromis niloticus) fed soybean meal-based diets. Aquacult. Nutr., 22: 457- 
464. https://doi.org/10.1111/anu.12266

Almeida, D.B., Da Costa, M.A.P., Bassini, L.N., Calabuig, C.L.P., Moreira, C.G.A., Rodrigues, M.D.N., Pe'rez, H.J., Tavares, R.A., Varela Jr, A.S. and Moreira, H.L.M., 2013. Reproductive performance in female strains of Nile tilapia, Oreochromis niloticus. Aquacult. Int., 21: 12911300. https://doi.org/10.1007/s10499-013-9630-0

Brian, O., 2015. Effect of tank background colour on the hatchability of Oreochromis niloticus eggs and survival of fry. Int. J. Fish. aquat. Stud., 2: 81-86.

Chaughtai, M.I., Mehmood, K. and Awan, R., 2015. Growth performance of carp species fed on salttolerant roughages and formulated feed in brackish water under polyculture system. Pakistan J. Zool., 47: 775-781.

Chowdhury, D.K., 2011. Optimal feeding rate for Nile tilapia (Oreochromis niloticus). M. Sc. thesis, Department of Animal and Aquacultural Sciences, Norwegian University of Life Sciences, pp. 76.

Cnaani, A. and Hulata, G., 2011. Improving salinity tolerance in tilapias: past experience and future prospects. Israel J. Aquacult. Bamid., 63: 1-21.

Daudpota, A.M., Abbas, G., Kalhoro, I.B., S S.S.A., Kalhoro, H., Rahman, M.H. and Gaf A., 2016. Effect of feeding frequency on grow performance, feed utilization and body composition of Nile tilapia (Oreochromis niloticus) cultured in low salinity water. Pakistan J.Zool., 48:171-177.

Daudpota, A.M., Siddiqui, P.J.A., Abbas, G., Narejo, N.T., Shah, S.S.A, Khan, N. and Dastagir, G., 2014. Effect of dietary protein level on growth performance, protein utilization and body composition of Nile tilapia cultured in low salinity water. Int. J. Interdis. Multidis. Stud., 2: 135-147.

Dawczynski, C., Martin, L., Wagner, A. and Jahreis, G., 2010. N-3 LCPUFA-enriched dairy products are able to reduce cardiovascular risk factors: a doubleblind, cross-over study. Clinic Nutr., 29: 592-599. https://doi.org/10.1016/j.clnu.2010.02.008

De Silva, S.S., 2016. Culture based fisheries in Asia are a strategy to augment food security. Fd. Sec., 8: 585-596.

FAO, 2011. World aquaculture 2010. FAO Fisheries and Aquaculture Technical Paper No. 500/1, FAO, Rome, Italy, pp. 120.

FAO, 2014. The state of world fisheries and aquaculture 2014. Rome, Italy, pp. 223.

Fitzsimmons, K., Garcia, R.M. and Gonzalez-Alanis, P., 2011. Why tilapia is becoming the most important food fish on the planet. In: Proceedings of the 9th International Symposium on Tilapia in Aquaculture (eds. L. Liping and K. Fitzsimmons). Shanghai, 1-8, pp. 409.

Fujimura, K. and Okada, N., 2007. Development of the embryo, larva and juvenile of Nile tilapia Oreochromis niloticus (Pisces: Cichlidae). Develop. stag. Syst. Develop. Grow. Different., 49: 301-324. https://doi.org/10.1111/j.1440-169X.2007.00926.x

Hussain, M.G., 2004. Farming of tilapia: Breeding plans, mass seed production and aquaculture techniques. Momin Offset Press, Dhaka, Bangladesh, pp. 149.

Iqbal, K.J., Ashraf, M., Javid, J., Abbas, F., Rehman, M.H., Khan, N., Rafique, M.K., Rasool, F., Azmat, H., Altaf, M. and Irfan, M., 2016. Effect of different plant and animal origin (fishmeal) feeds on digestive enzyme activity and hematology of juvenile Labeo rohita. PakistanJ. Zool., 48: 201-207.

Iqbal, K.J., Qureshi, L.A, Ashraf,M., Rehman, M.H.U., Khan, N., Javid, A., Abbas, F., Mushtaq, M.M.H., Rasool,F. and Majeed, H., 2012. Effect of different salinity levels on growth and survival of Nile tilapia (Oreochromis niloticus). J. Anim. Pl. Sci., 22: 919922.

Jarwar, A.M.A., 2006. Water-logged areas for fish ming. Daily Dawn Karachi, January 16, 2006.

Jarwar, A.M.A., 2014. Using saline groundwater for aquaculture. Daily Dawn Karachi, July 14, 2014.

Jaspe, C.J. and Caipang, C.M.A., 2011. Small-scale hatchery and larval rearing techniques for local strains of saline tolerant tilapia, Oreochromis spp. ABAH Bioflux, 3: 71-77.

Kevin, F., Janjua, R.S.N. and Ashraf, M., 2015. Aquaculture handbook, fish farming and nutrition in Pakistan, pp. 441.

Khalfalla, M.M., Hammouda, Y.A., Tahoun, A.M. and Abo-State, H.A.M., 2008. Effect of brood-stock sex ratio on growth and reproductive performance of blue tilapia Oreochromis aureus (Steindachner) reared in hapas. Proceedings of 8th International Symposium on Tilapia in Aquaculture, pp. 115-124.

Malik, A., Abbas, G., Kalhoro, H., Kalhoro, I.B., Shah, S.S.A. and Kalhoro, H., 2017. Optimum Salinity level for seed production and survival of Red Tilapia (Hybrid) in concrete tanks. Pakistan J. Zool., 49: 1047-1056. https://doi.org/10.17582/ journal.pjz/2017.49.3.1049.1056

Martins, G.B., Sergio, R.N.P., Juvencio, L.F.P., Denise, C.B. and Ricardo, B.R., 2015. Salinity on artificial reproduction of silver catfish (Rhamdia quelen). Ciência Rural, Santa Maria, Anim. Prod., 45: 458463.

Mashaii, N., Rajabipour, F., Mohammadi, M., Sarsangi, H., Bitaraf, A., Hossein-Zadeh, H. and Sharif- 
Rohani, M., 2016. Reproduction of Nile tilapia, Oreochromis niloticus in brackish water. J. appl. Aquacult., 28: 1-8. https://doi.org/10.1080/104544 38.2015 .1104943

Mateen, A., Afzal, M., Ahmad, I. and Hafeez-urRehman, M., 2004. Salinity tolerance of Rohu (Labeo rohita) and its hybrid under different temperature regimes. Int. J. agric. Biol., 6: 10301032.

Mubarik, M.S., Ismail, A. Hussain, S.M., Jabeen, F., Samiullah, K., Yaqub, S., Ahmad, S., Feroz, K., Khan, M.T., Nazli, S. and Ahmad, B., 2015. Survival, growth and body composition of Cyprinus carpio under different levels of temperature and salinity. Int. J. Biosci., 6: 132-141. https://doi. org/10.12692/ijb/6.10.132-141

Nandlal, S. and Pickering, T., 2004. Tilapia fish farming in Pacific Island countries. Volume 2. Tilapia growout in ponds. Noumea, New Caledonia: Secretariat of the Pacific Community. pp, 49.

Olufeagba, O. and Okomoda, V.T., 2015. Preliminary report on genetic improvement of Heterobranchus longifilis through Intra-specific hybridization of different strains from Nigeria. J. Aquacult. Fish Res., 1: 45-48.

Rehman, M.H., Ashraf, M., Abbas, F., Iqbal, K.J. Qureshi, I.A. and Andleeb, S., different synthetic hormones and their analogues on induced spawning in Channa marulius. Rakistan J. Zool., 47: 745-752.

Rodriguez-Montes De Oca, G.A., Román-Reyes, J.C.,
Alaniz-Gonzalez, A., Serna-Delval, C.O., MuñozCordova, G. and Rodríguez-González, H., 2015. Effect of salinity on three tilapia (Oreochromis sp.) strains: hatching rate, length and yolk sac size. Int. J. aquat. Sci., 6: 96-106.

Ronald, N., Gladys, B. and Gasper, E., 2014. The effects of stocking density on the growth and survival of Nile tilapia (Oreochromis niloticus) fry at Son Fish Farm, Uganda. J. Aquacult. Res. Dev., 5: 222-227. https://doi.org/10.4172/2155-9546.1000222

SEAFISH, 2011. Responsible sourcing guide: Tilapia farming. Origin Way, Europarc, Grimsby DN37 9TZ t, UK, pp. 1-9.

Siriwardhana, N., Kalupahana, N.S. and MoustaidMoussa, N., 2012. Health benefits of n-3 polyunsaturated fatty acids. Eicosapentaenoic acid and docosahexaenoic acid, $A d v$. Fd. Nutr. Res., 65: 211-222. https://dai.org/10.1016/B978-0-12416003-3.00013

Valeta, J.S., Likongwe, J.S., Kassam, D. and Maluwa, AO., 2013. Temperature dependent egg, development rates, hatchability and fry survival rate of lake Malawi Tilapia (Chambo), Oreochromis karongae (Pisces: Cichlidae). Int. J. Fish. Aquacult., 5: 55-59.

ong-Sulem, S., Brummett, R.E. and Tchoumboué, J., 2008. Hatchability of African catfish, Clarias gariepinus eggs in hapas and in basins: A diagnostic study of frequent Inhibition by rainfall and water stagnation. Tropicultura, 26: 39-42. 